\title{
Why and how to include parents in the treatment of adolescents presenting Internet gaming disorder?
}

\author{
CÉLINE BONNAIRE ${ }^{1,2 *}$, HOWARD A. LIDDLE ${ }^{3}$, ALEXANDRE HAR ${ }^{4}$, PHILIPPE NIELSEN ${ }^{5}$ and OLIVIER PHAN $^{2,4,6}$ \\ ${ }^{1}$ Université de Paris, LPPS, F-92100 Boulogne-Billancourt, France \\ ${ }^{2}$ Centre Pierre Nicole, Consultation Jeunes Consommateurs, Croix-Rouge Française, Paris, France \\ ${ }^{3}$ Miller School of Medicine, University of Miami, Coral Gables, FL, USA \\ ${ }^{4}$ Clinique Dupré, Fondation Santé des étudiants de France, Sceaux, Hauts de Seine, France \\ ${ }^{5}$ Centre Phénix Mail, Fondation Phénix, Geneva, Switzerland \\ ${ }^{6}$ Unité Inserm CESP U1018, Paris 5, France
}

(Received: November 29, 2018; revised manuscript received: April 10, 2019; accepted: April 21, 2019)

\begin{abstract}
Background and aims: Clinicians and researchers are increasingly interested in investigating excessive use of video gaming recently named Internet gaming disorder (IGD). As is the case with extensively researched adolescent problem behaviors such as substance use disorder, several studies associate IGD with the young person's family environment and the parent-adolescent relationship in particular. Evidence-based treatments for a range of adolescent clinical problems including behavioral addictions demonstrate efficacy, the capacity for transdiagnostic adaptation, and lasting impact. However, less attention has been paid to developing and testing science-based interventions for IGD, and at present most tested interventions for IGD have been individual treatments (cognitive behavioral therapy). Methods: This article presents the rationale for a systemic conceptualization of IGD and a therapeutic approach that targets multiple units or subsystems. The IGD treatment program is based on the science-supported multidimensional family therapy approach (MDFT). Following treatment development work, the MDFT approach has been adapted for IGD. Results: The article discusses recurring individual and family-based clinical themes and therapeutic responses in the MDFT-IGD clinical model, which tailors interventions for individuals and subsystems within the young person's family. Discussion and conclusions: Basic science developmental research can inform conceptualization of IGD and a systemic logic model of intervention and change. This paper aims to expand treatment theorizing and intervention approaches for practitioners working with frequently life-altering behaviors of excessive Internet gaming. We operationalize this aim by addressing the question of why and how parents should be involved in youth IGD treatment.
\end{abstract}

Keywords: Internet gaming disorder, parents, adolescents, family relationships, multidimensional family therapy

\section{INTRODUCTION}

Internet gaming, a global phenomenon, has become one of the most popular leisure activities among children and adolescents. Although it remains recreational for most, clinicians and empirical studies report that some adolescents engage in extensive Internet gaming with associated difficulties in everyday functioning (Gentile, 2009; King, Delfabbro, Doh, et al., 2018; Kuss \& Griffiths, 2012). In 2013, Internet Gaming Disorder (IGD) was included in Section III of the latest version of the Diagnostic and Statistical Manual of Mental Disorders (American Psychiatric Association, 2013) and Gaming Disorder has been added to the 11th World Health Organization's classification (WHO, 2018). Because of the several similarities between IGD and other addictive disorders (King, Delfabbro, Potenza, et al., 2018), such as substance use disorders (SUD; Ko et al., 2014), IGD treatment developers are using the theory and clinical methods from the youth addictions specialty as a reasonable starting point for their work. However, IGD and SUD are not directly transposable and further discussions are necessary to find accurate diagnostic criteria of IGD (Griffiths et al., 2016; Kardefelt-Winther et al., 2017). These criteria must be empirically based and should be rooted in an understanding of IGD's underlying mechanisms (Tunney \& James, 2017). Simultaneously, given the increasing demands for IGD treatment, the establishment of coherent treatment for this disorder is necessary (Rumpf et al., 2018). In this regard, existing basic science in developmental psychopathology and advances in how to develop and adapt interventions, the availability of effective youth treatments can be levered to specify new IGD interventions, as well as arguments on clinical and public health considerations (Rumpf et al., 2018).

* Corresponding author: Céline Bonnaire; Université de Paris, LPPS, F-92100 Boulogne-Billancourt, France; Phone: +33 176 5329 52; E-mail: celine.bonnaire@parisdescartes.fr

This is an open-access article distributed under the terms of the Creative Commons Attribution-NonCommercial 4.0 International License, which permits unrestricted use, distribution, and reproduction in any medium for non-commercial purposes, provided the original author and source are credited, a link to the CC License is provided, and changes - if any - are indicated. 
Cognitive behavioral therapies (CBTs) are firmly established in the addiction treatment field and thus far CBT clinical conceptualizations and treatments predominate in the IGD specialty as well (King et al., 2017). However, in relevant research, particularly in lines of treatment research with adolescent SUD and behavioral problems, familybased treatment and prevention theories and methods evidence a strong empirical base. For adolescent SUD, family-based interventions show a comparative superiority over individual therapies (Tanner-Smith, Wilson, \& Lipsey, 2013). In behavioral addictions such as gaming and gambling for instance, an expanding empirical base has explored parent and family factors associated with the problem behavior (Kourgiantakis, Saint-Jacques, \& Tremblay, 2013; Schneider, King, \& Delfabbro, 2017) and interventions targeting these problems (Federman, Drebing, \& Krebs, 2000; Zajac, Ginley, Chang, \& Petry, 2017). In their review, Schneider et al. (2017, p. 331) conclude that "the influence of the family system is vitally important to address within interventions for adolescents" presenting IGD. Considering the movement to conceptualize problems transdiagnostically, and in terms of the cross-cutting mechanisms of different symptoms or diagnoses (Franklin, Jamieson, Glenn, \& Nock, 2015), and the demonstrated effectiveness of several family therapies to treat problems of adolescents, family-based interventions should be considered as viable candidates for adaptation, application, and research concerning IGD.

This article presents clinically relevant content from the empirical work from the developmental psychopathology research literature. We do so to broaden the conceptualization of IGD. We argue for a systemic orientation to IGD so that both individual level and proximal psychosocial environment factors can be used to guide treatment. The clinical orientation of the paper is multidimensional family therapy (MDFT), an evidence-supported treatment for youth substance abuse and related behavior problems (Liddle, 2016a). Several randomized clinical trials have established the efficacy of the MDFT with moderate-to-severe drugabusing adolescents (Henderson, Dakof, Greenbaum, \& Liddle, 2010; Liddle, Rowe, Dakof, Henderson, \& Greenbaum, 2009; Weinberg, Rahdert, Colliver, \& Glantz, 1998), and youth presenting with conduct disorder (Boustani, Henderson, \& Liddle, 2016). MDFT recognizes the central role of the family in the development and treatment of adolescents' drug use problems (Liddle et al., 2001; Muck et al., 2001), and its intervention orientation is based on empirical research covering normative adolescent development and developmental psychopathology (Liddle et al., 1998). The approach addresses the multiple subsystems in which people live both within and beyond the context of the family (Liddle \& Rigter, 2013).

Empirically based and clinically based arguments can illustrate the relevance of family therapy for adolescents with IGD. From a basic science and developmental perspective, the family is the primary unit of socialization for children, and even though the nature of family relationships changes during adolescence, the developmental importance of the parent-child relationship remains vital. From a clinical perspective, including parents in treatment is based on a systemic conceptualization of clinical problems (i.e., examining multiple sources of both good functioning and dysfunctions and examining behaviors/ problems in context), and this conceptualization of the problem is supported by basic science - the development of problem behaviors in youth leading to psychopathology. Thus, the aim of this article is to present an empirical and clinical rationale for including parents in the treatment of adolescents presenting IGD. Our goal is not only to answer the question of why parents should be involved in youth IGD treatment but also how to include and work with them.

\section{THE BASIC SCIENCE OR DEVELOPMENTAL CASE FOR INCLUDING PARENTS}

\section{Family relationships: A well-established protective factor from behavioral disorders}

Emotional distance and extreme conflict between adolescents and their parents are not normative (Steinberg, 2014). In fact, no factor seems to influence adolescent adjustment more than the quality of family relationships (Garnefski, 2000; Kaminski et al., 2010; Repetti, Taylor, \& Seeman, 2012), specifically "the teenager's feeling of connectedness with parents and family" (Blum \& Rinehart, 2000, p. 31). Parent-adolescent relationships influence the development and prevention of risky adolescent health behaviors (Riesch, Anderson, Pridham, Lutz, \& Becker, 2010) and protect against a variety of externalizing and internalizing problem behaviors (Resnick et al., 1997). In the addiction literature, family relationship quality and the parenting process appeared as strong protective factors from the emergence of substance abuse, especially in adolescents (Blustein et al., 2015; Donovan, 2004; Keijsers, 2016; King, Molina, \& Chassin, 2009; Waldron, Brody, Robbins, \& Alexander, 2013).

IGD research is still in an early stage. Nevertheless, in several studies, IGD was associated with poor family relationships (Bonnaire \& Phan, 2017; Chiu, Lee, \& Huang, 2004), and positive parent-child relationships were found to be protective factors against IGD (Chiu et al., 2004; Da Charlie, HyeKyung, \& Khoo, 2011; Kwon, Chung, \& Lee, 2011; Liau et al., 2015; Yang \& Tung, 2007). IGD gamers tend to come from less warm, cohesive families (Bonnaire \& Phan, 2017; Choo, Sim, Liau, Gentile, \& Khoo, 2015; Rikkers, Lawrence, Hafekost, \& Zubrick, 2016; Wang et al., 2014; Zhu, Zhang, Yu, \& Bao, 2015; Zorbaz, Ulas, \& Kizildag, 2015), and low parental support (Baier \& Rehbein, 2009) and low paternal adaptability (Tafa \& Baiocco, 2009) have been associated with IGD. Thus, the quality of parent-adolescent relationships is an agreed upon behavioral target in youth intervention programs, given its centrality in the developmental health of the adolescent and the acquisition of essential life skills (e.g., emotion regulation as discussed below). Along these lines, it might be useful to recall that family therapy originally sought to articulate theory and practice in order to change dysfunctional transactional family patterns that connect to the development of problem behaviors (Liddle, 2010). Parallel and intersecting with this transactional change target are individual sessions with the parent(s) and with the young 
person, which also address the parent-youth relationship, as well as more "individual" aspects of each family member's life (e.g., the parent's functioning as an individual, outside of their role as a parent; the young person's functioning in multiple developmental realms such as identity, peer relations, and emotion regulation). Youth engaged in MDFT reported improvements in relationships with their parents (Henderson, Rowe, Dakof, Hawcs, \& Liddle, 2009; Liddle et al., 2009). Moreover, behavioral observational methods show improvement in family functioning (e.g., reductions in family conflict and increment in family cohesion) to a greater extent with MDFT than other therapies, with these benefits remaining present at follow-up 1 year later (Liddle et al., 2001).

\section{Parenting style: A way of helping adolescents grow up in healthy ways}

Many studies have demonstrated a relationship between parenting and the adolescent's healthy development (see Davids, Roman, \& Leach, 2017; Newman, Harrison, Dashiff, \& Davies, 2008 for systematic reviews). Parenting styles can be specified (authoritarian, authoritative, permissive, and neglectful; Baumrind, 1967; Maccoby \& Martin, 1983), and associations exist between parenting styles and youth outcomes. Adolescents raised in authoritative households consistently presented with more protective behaviors and fewer risk behaviors than adolescents from non-authoritative families. Parenting styles and behaviors related to warmth, communication, and disciplinary practices predict important outcomes including academic achievement and psychosocial adjustment (Cutrona, Cole, Colangelo, Assouline, \& Russell, 1994).

In the addiction field, numerous studies have shown a relationship between parental monitoring and substance use in adolescents (Kaltiala-Heino, Koivisto, Marttunen, \& Fröjd, 2011; Wang, Dishion, Stormshak, \& Willett, 2011), and have suggested a decreased risk of substance use among adolescents whose parents had an authoritative parenting style and an increased risk for adolescents whose parents had permissiveness/indulgence, neglectful/unengaged, or authoritarian parenting (Cablovà, Pazderkovà, \& Miovsky, 2014; Davids et al., 2017). In the media research domain, the concept of parental mediation (e.g., parents' efforts to protect their children from exposure to dangers online; Livingstone, 2007) appeared as a protective factor (Mesch, 2009; Rosen, Cheever, \& Carrier, 2008). Optimal parenting (defined as parents that care for and protect their child yet respect their autonomy; Floros \& Siomos, 2013) and restrictive mediation (which refers to parental rules and regulations on children's media use; Chng, Li, Liau, \& Khoo, 2015) are negatively associated with pathological Internet use. Only a few studies have examined the association between parenting style and video game use and they yield mixed findings (Chiu et al., 2004; Shin \& Huh, 2011). Studies on gaming rules seem to differ according to the gender of the child. Restriction may be more important for females to curb excessive gaming. Males seem to benefit from clear rules about gaming use like time to begin and time to end gaming accompanied by non-authoritative parental vigilance (Bonnaire \& Phan, 2017). Although still an open question, the effect of the parent-child relationship on IGD may be stronger for boys than for girls (Choo et al., 2015; Wallenius \& Punamäki, 2008).

Parenting practices are fundamental and for some experts, the evidence supporting authoritative parenting is so strong that the question of which type of parenting benefits adolescents the most need minimal addititional study (Steinberg, 2001). Perhaps, parenting practices hold the potential to reduce the effect of moderators that are less changeable (such as media exposure, poverty, and neighborhood risks) on subsequent youth behavior (Newman et al., 2008). Thus, the major influence that parenting styles and behaviors exert on youth risks and protection indicates a clear need for more family-based interventions to improve adolescent health outcomes. Based on empirical data, which have shown that parenting practices improve in MDFT (Schmidt, Liddle, \& Dakof, 1996), MDFT seems a promising family-based therapy for IGD. In the basic MDFT approach, therapists actively guides, coaches, and shapes more positive and constructive family interchange during family sessions (Liddle, 2016b). IGD therapists work to establish a more concrete thinking through about and better communication of rules about video game use to the youth. Within a harm-reduction philosophy, video game abstinence is not necessarily a realistic goal. Sessions attempt to foster a mutual agreement about reducing the amount of video game time (Ramirez et al., 2011). Furthermore, in sessions with parents, therapists focus on establishing adequate agerelated rules and behavioral follow through with their rules with appropriate consequences.

\section{Emotion regulation: The role of the family context}

Developmental research and theory suggest that a core component of children's successful development is learning how to regulate emotional responses and related behaviors in socially appropriate and adaptive ways (Denham et al., 2003; Eisenberg, Spinrad, \& Morris, 2002; Halberstadt, Denham, \& Dunsmore, 2001). The role of emotion regulation in atypical development (Cicchetti, Ackerman, \& Izard, 1995; Frick \& Morris, 2004; Steinberg \& Morral, 2003) is well established (for addictive disorders, see Sloan et al., 2017 for a review). Emotional experiences are one of the bases of the self (Lupton, 1998) and enable subjects to enter into relationships with the surrounding world (Lyon \& Bardalet, 1994). Reaching emotional self-sufficiency and autonomy is a core milestone of adolescence (Hill \& Holmbeck, 1986). Young people need to regulate emotion independently of their attachment figures (Allen \& Miga, 2010).

Our developing intervention theory for IGD suggests that for some adolescents, playing video games is a maladaptative strategy used to cope with individual and familial difficulties. Excessive video gaming can be considered as an escape strategy, or as proposed by Hayes et al. (1996), an experiental avoidance of painful aspects of real life. This clinical perspective is in line with the four-factor model of IGD cognition proposed by King and Delfabbro (2016). Most IGD adolescents stay in front of their screen instead of exploring the environment, going out for new experiences, new relationships, and therefore developing their autonomy. Reality exploration, as is expected in attachment theory with 
adolescents (Dubois-Comtois, Cyr, Pascuzzo, Lessard, \& Poulin, 2013), seems to be replaced by virtual game reality exploration. IGD adolescents appear to blur the boundaries between realities: game reality takes priority over the everyday reality of family and social lives. The body invested is one of the avatars. The young person's body in reality is left out, as if they were disconnected from their own bodily sensations and emotions. From their point of view, game partners are part of their social network and they are sharing emotions with them. It is not uncommon for these youth to not recognize that relationships outside of the virtual world intimidate them and represent significant emotional challenges. It seems that through gaming they avoid or suppress negative emotions and experience positive ones. Several studies confirm this clinical observation. Adolescents were found to play video games in order to escape from daily life and forget about worries (Wallenius, Rimpelä, Punamäki, \& Lintonen, 2009). Poor peer attachment (Estévez et al., 2017) and low social competence (Wichstrøm, Frode Stenseng, Belsky, von Soest, \& Hygen, 2018) predicted IGD since teenagers use video games as a refuge (Vollmer, Randler, Horzum, \& Ayas, 2014), and or as an effective, albeit non-face-to-face form of its relationship satisfaction (Estévez et al., 2017). Low levels of emotion regulation or poor emotion regulation skills are associated risks of IGD (Estévez et al., 2017; Wichstrøm et al., 2018).

Considering these findings, therapists needs to create a climate of trust to allow the adolescent to connect with emotions, express them, and develop improved regulation behaviors. This and other developmental challenges are not all intrapersonal or individually based (i.e., thought of as individual adolescent competencies). A critical developmental research finding, with important clinical implications, is that parents play a fundamental role in emotion regulation skills (Morris, Silk, Steinberg, Myers, \& Robinson, 2007) and the adolescent needs to acquire emotional competencies to leave the screen, go out, and develop relationships with peers. As highlighted by Estévez et al. (2017), disrupted relationships between parents and adolescents can prevent the acquisition of emotion regulation and maintain a dysfunctional distance (or proximity) between parents and adolescent. Thus, there is a need to repair the relationship or attachment bond to foster emotional skill acquisition and from that base, invest in exploring of the surrounding world. To do so, it is important for the parents to talk differently about video games and gaming. Talking about gaming is a way for parents to help their adolescent identify and express what they feel when they play video games and begin to think about different ways of regulating emotions. For example, when the adolescent is failing in his game and becomes aggressive and violent, parents could help the adolescent discover different ways in which to express their frustration, anger, and disappointment. In talking by this way, parents contain the emotions that their adolescent is experiencing while playing and help him find different ways of expressing, controlling, and regulating his emotions. Each arousal, each sensation, each emotion that the adolescent is feeling in the game needs to find a meaning and the adolescent needs to have the words to describe what he is experiencing. In agreement with Coulombe (2010), thanks to language (thus thanks to the meaning), the adolescent will be able to develop a critical distance regarding video games, as a reflexive counterweight to its power of fascination.

\section{THE CLINICAL CASE FOR INCLUDING PARENTS}

\section{Inclusion of parents in the treatment process promotes adolescents' initial engagement and ongoing participation in treatment}

One of the most robust findings in adolescent SUD treatment literature is that retention in therapy is essential for obtaining a successful treatment outcome (Stark, 1992; Stevens \& Morral, 2003). Nevertheless, adolescents are generally reluctant to enter into therapy (Rubenstein, 2005) and the lack of engagement of one of the family members in the therapeutic process can have a detrimental effect on all the family's experience (Higham, Friedlander, Escudero, \& Diamond, 2012). From our clinical experience, most adolescents presenting IGD do not enter into treatment on their own initiative and are reluctant or downright opposed to treatment.

Several empirical studies showed that family-based therapy is more effective than other well-established adolescent drug abuse treatments in terms of the engagement and retention of adolescent in the therapy (see Becker, Boustani, Gellatly, \& Chorpita, 2018; Tanner-Smith et al., 2013 for reviews). Family members, especially parents, are instrumental in facilitating the adolescent's change process (Huey, Henggeler, Brondino, \& Pickrel, 2000) and enhance treatment success, especially for reluctant adolescents (Higham et al., 2012). In the case of MDFT, controlled trials support the engagement, retention, and outcome superiority of MDFT compared to standardized treatment, including CBT (Liddle, 2016a; Liddle et al., 2009). Thus, given the capacity of MDFT to meet the most difficult treatment challenges of clinically referred youth (Diamond, Diamond, \& Liddle, 2000) in controlled trials and implementation studies, MDFT appears as a promising approach for IGD.

Why is MDFT efficient at engagement? Parents with an addictive teenager are discouraged, exhausted, overwhelmed, and feel like they have tried everything and that nothing will work anymore. They come to the addiction treatment center as a last resort. Yet, MDFT therapeutic attitude is optimistic about change, is focused on strengths, and is energetic, which is demonstrated in the way that the therapist establishes multiple therapeutic alliances with different family members (Liddle, Dakof, \& Diamond, 1991; Liddle, Dakof, Henderson, \& Rowe, 2011). Therapeutic alliance is one of the biggest predictors of therapeutic outcomes (Friedlander, Escudera, Heatherington, \& Diamond, 2011; Martin, Garske, \& Davis, 2000) and studies have shown a negative relationship between the quality of therapeutic alliance and therapy dropout (Robbins, Liddle, Turner, Dakof, \& ALexander, 2006). Furthermore, the results suggest that, while the strength of the parenttherapist alliance appears to influence treatment completion, 
the strength of the alliance with the adolescent appears to impact on treatment outcome (Shelef, Diamond, Diamond, \& Liddle, 2005). Including parents in the treatment has one significant immediate effect: it changes the negative perception of the adolescent coming to the treatment center. It allows the teenager to get out of the position of identified patient (Runkel, Christenson, Glunz, \& Cobb, 2017), avoiding the notion of sole responsibility for the situation. Including parents in therapy allows the adolescent to feel that he is not the only "caretaker" of the situation, which relieves him. It co-empowers all family members. Especially, because he is generally in denial of his problematic behavior, his only "complaint" concerns his parents. Thus, occassionally, engaging parents might be the only way to maintain adolescents in treatment durably. Therefore, one of the main challenges for family therapists is to simultaneously engage in multiple therapeutic alliances and engage several family members who may be in conflict with each other and have different levels of motivation for treatment (Friedlander, Escudera, \& Heatherington, 2006). One specificity of MDFT is that the therapist works with the family system but also with the subsystems of the parents on one hand and the teenager on the other hand. This work favors the building of therapeutic alliances and is "easier" when the families are in crisis, which is the case for almost all IGD families. With the whole family, the risk is to make an alliance with one or the other and to reproduce in therapy what they live on a daily basis. Several studies on MDFT provide some guidance about the types of therapist interventions that may hinder the establishment of alliances: therapist who are in too much of a hurry to engage in problem solving with the adolescent (Diamond, Liddle, Hogue, \& Dakof, 1999) or parents (Schmidt et al., 1996) and do not follow the protocolized stages of the approach to engagement with the parent and adolescent (Diamond et al., 1999). Thus, therapeutic alliance plays an important role in treatment retention in family therapy but it is important to disentangle the factors associated with variability in alliance, therapist intervention, and retention (Robbins et al., 2006). Indeed, there is a need to identify specific therapist interventions that facilitate the formation of alliances with adolescents and parents. Although for both this will include an exchange about video games, the clinical work is different with the parents and with the teenager (see the following points).

\section{One of the main parents' complaint is "I cannot stop my adolescent from playing video games"}

When they seek therapy, parents mainly complain about the obstacles they face when trying to regulate the use of video games. This means that they have difficulty posing an act of authority, setting clear rules about video game use and enforcing them. The difficulty in solving this problem can lead parents to feel guilty, to lose confidence in their parental competences, and to withdraw from therapy. Thus, the therapist must attend to this level of alliance with the parents very early to reduce the risk of dropout (Robbins et al., 2006). In MDFT, one major task of the first stage of subsystem work with parents is to make them feel that they are helpful and influential in their teenagers' life, to engage them in therapy (Liddle, 2000). The goal is to interrupt the cycle of defeat, desperation, and emotional distancing that parents experience and to revive their hopes, dreams, connection with, and aspirations for their teenagers. The MDFT therapist needs to create processes inside and between family members that are ingredients and promoters of change. One of these processes is to allow the parents to truly experience what they have been going through. Slowly, gradually, with empathy, hope, and new perspectives of the situation, the MDFT therapist connects parents with their pain and suffering in past and current situations, which in turn contributes to connect and reconnect parents to their loving and caring about their child. Engagement, which is key to change, could be defined as an engagement with the self, and for the parent, a potential engagement or reengagement with their teenager. Furthermore, parents need to recognize and reconnect with their parental skills. Therapist look for and build on examples of parenting practices that have been successful. As recommended in MDFT Stage 1 (i.e., "Build the foundation"), and these everyday parenting actions become a platform to work on new rules about video game use (i.e., Stage 2: "Prompt action and change"). Here, the therapist can increase parents' knowledge about and then practice effective parenting practices (Liddle, 2000).

There are two specific features of parents of adolescents presenting with IGD. The first one is that most of them have a difficulty integrating or understanding that children/ adolescents need to be educated on screens/video game use. For the parents, because their child is born with video games around, it is assumed that they should know how to make good use of them and how to stop at the right time. They also fail to understand that technical mastery does not imply cognitive and emotional mastery. The second feature is that for many reasons, parents did not always monitor video game use in the past, and they introduced the games early into the home. However, because of all the current negatives consequences, more or less suddenly and quite brutally for the teenager, the parents begin to forbid an activity that they have never really controlled so far and begin to be extremely critical about video games. They become authoritarian in a unilateral approach. Video games are presented as responsible for all failures and all the negative aspects of the teenager's life. Yet, negative parental attitudes toward gaming are associated with more symptoms of IGD (Jeong \& Kim, 2011) and parental supervision of gaming is negatively associated with IGD (Bonnaire \& Phan, 2017; Rehbein \& Baier, 2013). This means that the therapist must work with parents on setting rules and limits and move from the "absence" of rules to a controlled use of video games. This means that parents will move from a logic of all or nothing to a logic of negotiation and co-construction. Similar to children, adolescents need rules and limits because structure makes them feel secure (Steinberg, 2004). Children gradually develop the ability to manage themselves: they acquire this skill and parents are essential in this learning process until late adolescence. Here, the therapist can help parents understand why the adolescent cannot limit himself by explaining the recent work of neuroscience (i.e., the part of the brain in which executive functions develop, essential for cognitive control, 
remains immature until early adulthood; Casey, Getz, \& Galvan, 2008; Steinberg, 2008).

Nevertheless, before working on video game use rules, the therapist must work on parents' ambivalence and on their perception of video games. Indeed, even if parents want their child to have a controlled use of video games, deep down they would like him to no longer play at all. But setting rules does not mean forbidding. On the one hand, it is inconceivable to ban an activity that almost all teenagers practice. In addition, this activity contributes to the enjoyment and acquisition of many skills (see Bediou et al. 2018; Granic, Lobel, \& Engels, 2014 for reviews). Indeed, it is important for parents to know the benefits of playing video games. On the other hand, the teenager cannot accept that his parents suddenly forbid the use of video games when they had always let him play beforehand. Thus, the therapist must help parents to set clear limits, which are adapted to the teenager's current game playing. The teenager will not be able to go from $10 \mathrm{hr}$ per day to $1 \mathrm{hr}$. Furthermore, this cannot be done without the contribution of their teenager. Indeed, collaborative problem-solving is the most effective strategy to solve conflict (Steinberg \& Levine, 1997). To reach a positive parent-adolescent relationship, parents need to gradually transform their use of authority from a unilateral approach to one of cooperative co-construction (Youniss \& Smollar, 1985). Clinical experiences show that the transition from authoritarian control to a collaborative parental-adolescent stance takes time to establish and settle. Time and building of a trusting relationship are major issues when parents are asking for quick changes and may not be willing to wait as much as needed. Establishing family changes is a step-by-step endeavor with intermediate phases that may appear dysfunctional. Parents must establish a contract with their teenager for the use of video games. Indeed, the teenager will willingly submit to a contract if he feels valued and if he agrees upon the rules of the contract. In order for parents to agree to work on the rules of use of video games and for the teenager to agree to talk about this with his parents, parents must stop talking about video games in purely negative terms.

\section{Conflicts and lack of communication between parents and adolescent}

As with SUD (Liddle, 2000), excessive blame, defensiveness, and recrimination are characteristics of early-stage conversations with families of adolescents presenting IGD. On one hand, parents tend to be critical and judgmental about their adolescent and these recriminations include video games; on the other hand, the adolescent tends to be either silent or aggressive. IGD takes place inside the family and therefore has a strong impact on family functioning. The more the adolescent plays video games, the more the parents harbor judgments about video games and the more the adolescent locks himself into video games and becomes mute. This shows how much therapists need to target family relationships and day-to-day communication. Indeed, high negative attitudes toward the patient and his disorder may be a fairly treatment-resistant family attribute (Doane, Hill, \& Diamond, 1991). When these negative exchanges persist, family members feel hopeless about change and dissatisfied with therapy
(Diamond \& Liddle, 1999) and the likelihood of non-compliance and early dropout increases (McMahon, Forehand, Griest, \& Wells, 1981). Clinically, chronic negative emotional expression during sessions has been associated with poor treatment outcome (Mann, Borduin, Henggeler, \& Blaske, 1990; Robbins, Alexander, Newell, \& Turner, 1996).

In MDFT, the therapist facilitates change directly in the parent-adolescent relationship through enactment (Diamond \& Liddle, 1996, 1999; Liddle, 2000). In MDFT, enactment gives an ecological picture of existing family relationships and a technique to shape new kinds of family interactions (Liddle, 1995). Thus, in the first stage of MDFT, the therapist works on family members' reconnection and particularly emotional reconnection. Parenting relationship interventions are designed to close the emotional distance between the parents and the adolescent - and more specifically to repair the attachment relationship - and reduce excessive conflict and negative affect (Liddle, Rowe, Dakof, \& Lyke, 1998). Decreasing the negative emotional charge will reconnect family members. To do so, the therapist needs to take time to build therapeutic alliance with the adolescent alone and with the parents alone. The MDFT therapist works processes of different types (intrapersonal and interpersonal) with different family members (Liddle \& Rigter, 2013). One important goal here is that video games are no longer a source of conflict and difficulties. Indeed, although parents perceive video games as a poison, the therapist sees it here as the cure. First, video games are will contribute to create the therapeutic alliance with the teenager; second, they will contribute to reconnect parents and adolescent, which will then allow therapy to address other difficulties and problems in the family. Thus, video games are perceived as the means of restoring communication between parents and adolescent.

Most IGD adolescents are not aware of their excessive use and even less aware of the function of video games (e.g., emotion regulation). IGD teenagers are usually shy, introverted, and inhibited (Bonnaire, 2015; Caplan, 2007). Thus, it is not easy for them to speak freely. It is therefore essential to be active and directive in the session, not to let silence settle down, and to show genuine interest in their video game. When it comes to talking about themselves, words are generally lacking, which is not the case when it comes to video games. It is essential that the therapist has some knowledge about video games. It is a way to be legitimate in the face of the teenager, and not to be compared to a parental figure who knows nothing about it and does not care about it. In addition, having knowledge in games allows therapist to pose important questions that make sense to the adolescent's practice. For the teenager, meeting an adult who has knowledge in the field of video games, who is authentically interested in them, and who does not judge them is a clinical fundamental element that contributes to build the therapeutic alliance.

The therapist needs to meet alone with the parents in order to hear and to empathically validate their suffering and worries. Indeed, as mentioned before, in MDFT, Stage 1 implies validation of parents' past efforts, and acknowledgement of difficult past and present circumstances. It is 
important for the therapist to be careful not to respond immediately to their request for a magic solution. Being in a hurry for change and engaging too quickly in problemsolving undermines therapeutic alliance building and increases the probability of stopping therapy (Doane et al., 1991). The therapist will not be able to set up problem-solving in the relational system if there is no change in the family emotional climate. Parents will not be able to try new educational behaviors or practice if their emotional involvement is low (Dix, 1991; Liddle et al., 1998; Patterson \& Chamberlain, 1994). However, the therapist can assist the parent's mentalization of the child's mind (Fonagy \& Bateman, 2005) and describe to parents the opportunity to look at things from a different perspective (Sorensen, 2005). Nevertheless, the therapist also needs to modify parents' perception of video game and help them get out of a critical and negative perception. Indeed, criticism about gaming has two main consequences: it reinforces adolescent video game use and maintains the lack of communication. Communication cannot be reestablished if there is significant emotional distance between parent-adolescent and an emotional climate full of hostility and disappointment (Burke \& Weir, 1978; Mann et al., 1990).

For the parents, reaching out and renewing communication is being able to meet the adolescent where he stands: in front of his screen, playing video games. This is not a peculiar challenge. Parents may feel that they are suppressing themselves and not feel at ease. Furthermore, video games distanced their adolescent from them. Prior to asking for change, parents need to discover what is really in their child's mind. Parents must talk with their adolescent about his video game and be interested in what he likes while he is playing. Parents usually mix up "showing an interest" and "liking it." The aim of talking about video games and being interested in them is not to love and become an expert in them but rather to get in touch and reconnect with their teenager. However, parents are extremely critical about video games and when they do this, the teenager withdraws because he feels poorly understood and rejected. Furthermore, adolescents generally do the opposite of what their parents advocate (this is a developmental logic; see Steinberg, 2004), so the more parents will criticize or even ban video games the more the teenager will play. Thus, parents must be skilled and recognize the positive aspects of video games. Indeed, this will allow parents to: (a) reestablish the communication with their teenager, (b) find a way to get to know him better, (c) see him in another light and change the (negative) perception of their adolescent, and (4) find a way to add value to their adolescent (who performs well in the game; Bonnaire, 2015). This work (along with other psychotherapeutic interventions) will contribute to move from an emotional climate full of negative emotions (e.g., anger, disappointment, fear of the future, and worries about schooling) to an emotional climate full of positive emotions (love, hope, pride, and kindness). This clinical challenge is an essential precondition before the prospect of change. Indeed, MDFT change mechanism studies (Diamond \& Liddle, 1996; Henderson et al., 2010; Schmidt et al., 1996) have shown that improvements in developmentally consequential aspects of the family system (parenting practices and more specifically negative parenting behaviors) are related to change at the critical level of interest - reduction of adolescent symptoms, including drug abuse.

\section{CONCLUSIONS}

Although acknowledging the early developmental stage of the specialty, systematic reviews on IGD treatments have specified several research needs. King et al. (2017) emphasized the paucity of well-designed treatment outcome studies and limited evidence for the effectiveness of any treatment modality. To date, no treatment for IGD meets the criteria for an evidence-based treatment. In line with this conclusion, Zajac et al. (2017) outline that no research has modeled IGD treatments on evidence-based treatments for adolescent SUD, for which the most effective are familybased. Our aim was to demonstrate the appropriateness of MDFT for IGD. One study on an intervention for Internet addiction showed that a multilevel treatment program that involved the adoption of a family perspective presented encouraging results in youth (Shek, Tang, \& Lo, 2009). Consequently, one might think that family therapy and more specifically therapy with a multidimensional conception could be very promising. Initially designed for adolescents presenting SUD and recognized as an evidence-based treatment, MDFT appears as a relevant treatment model for adolescents presenting IGD. Given the well-established transdiagnostic empirical evidence of MDFT (Liddle, 2016a), and its track record and systematic methodology of adaptation to fit different treatment settings and treat a range of various clinical disorders, MDFT can be considered a viable option for IGD treatment. MDFT reflects a practical, flexible, adaptive, and widely transportable approach (Liddle, 2016a). Two ongoing studies in France and Switzerland are adapting the MDFT approach to IGD cases. We hope these projects can contribute to the urgent need for clinical knowledge in this specialty.

Finally, it seems important that clinicians be more involved in the process of building an effective therapy for IGD. As outlined by Hershenberg and Goldfried (2015), it remains crucial to continue to design research that incorporates the perspective and expertise of the clinician. From a holistic perspective, social, cognitive, emotional, and behavioral variables investigated at multiple levels of analysis should be used to refine existing interventions (Hershenberg \& Goldfried, 2015).

Funding sources: None.

Authors' contribution: CB drafted the first version of the manuscript. All authors have corrected and provided suggestions to this first draft. It was sent back and forth with corrections several times between $\mathrm{CB}$ and the other authors. All authors agreed on the final version of the manuscript.

Conflict of interest: The authors declare no conflict of interest. 


\section{REFERENCES}

Allen, J. P., \& Miga, E. M. (2010). Attachment in adolescence: A move to the level of emotion regulation. Journal of Social and Personal Relationships, 27(2), 181-190. doi:10.1177/026540 7509360898

American Psychiatric Association. (2013). Diagnostic and statistical manual of mental disorders: DSM-5. Washington, DC: American Psychiatric Association.

Baier, D., \& Rehbein, F. (2009). Computerspielabhängikeit im jugendalter [Video game addiction in adolescence]. In C. J. Tuly (Ed.), Multilokalität und vernetzung: beiträge zur technikbasierten gestaltung jugendlich sozialträume [Multilocality and networking: Contributions to technology-based design teen social dreams] (pp. 139-155). Weinheim/München: Juventa Verlag.

Baumrind, D. (1967). Child-care practices anteceding three patterns of preschool behavior. Genetic Psychology Monographs, $75,43-88$.

Becker, K. D., Boustani, M., Gellatly, R., \& Chorpita, B. F. (2018). Forty years of engagement research in children's mental health services: Multidimensional measurement and practice elements. Journal of Clinical Child and Adolescent Psychology, 47(1), 1-23. doi:10.1080/15374416.2017.1326121

Bediou, B., Adams, D. M., Mayer, R. E., Tipton, E., Green, C. S., \& Bavelier, D. (2018). Meta-analysis of action video game impact on perceptual, attentional, and cognitive skills. Psychological Bulletin, 144(1), 77-110. doi:10.1037/bu10000130

Blum, R., \& Rinehart, P. (2000). Reducing the risk: Connections that make a difference in the lives youth. Minneapolis, MI: Division of General Pediatrics and Adolescent Health, University of Minnesota.

Blustein, E. C., Munn-Chernoff, M. A., Grant, J. D., Startor, C. E., Waldron, M., Bucholz, K. K., Bucholz, K. K., Madden, P. A. F., \& Heath, A. C. (2015). The association of low parental monitoring with early substance use in European American and African American adolescent girls. Journal of Studies on Alcohol \& Drugs, 76(6), 852-861. doi:10.15288/jsad.2015.76.852

Bonnaire, C. (2015). Prise en charge des joueurs problématiques de jeux vidéo et de leur famille [Treatment for problem gamers and their family]. In I. Varescon (Ed.), Le psychologue en addictologie [The psychologist in the addiction field] (pp. 189-206). Paris, In Press.

Bonnaire, C., \& Phan, O. (2017). Relationships between parental attitudes, family functioning and Internet gaming disorder in adolescents attending school. Psychiatry Research, 255, 104-110. doi:10.1016/j.psychres.2017.05.030

Boustani, M., Henderson, C. E., \& Liddle, H. A. (2016). Familybased treatments for adolescent substance abuse: How scientific advances yield new developmental challenges. In S. A. Brown \& R. A. Zuckerds (Eds.), The Oxford handbook of adolescent substance abuse. New York, NY: Oxford University Press.

Burke, R. J., \& Weir, T. (1978). Benefits to adolescents of informal helping relationships with their parents and peers. Psychological Reports, 42(3), 1175-1184. doi:10.2466/pr0.1978.42.3c.1175

Cablovà, L., Pazderkovà, K., \& Miovsky, M. (2014). Parenting styles and alcohol use among children and adolescents: A systematic review. Drugs: Education, Prevention, and Policy, 21(1), 1-13. doi:10.3109/09687637.2013.817536
Caplan, S. E. (2007). Relations among loneliness, social anxiety, and problematic Internet use. CyberPsychology \& Behavior, 10(2), 234-242. doi:10.1089/cpb.2006.9963

Casey, B. J., Getz, S., \& Galvan, A. (2008). The adolescent brain. Developmental Review, 28(1), 62-77. doi:10.1016/j.dr.2007. 08.003

Chiu, S. I., Lee, J. Z., \& Huang, D. H. (2004). Video game addiction in children and teenagers in Taiwan. CyberPsychology \& Behavior, 7(5), 571-581. doi:10.1089/cpb.2004.7.571

Choo, H., Sim, T., Liau, A. K. F., Gentile, D. A., \& Khoo, A. (2015). Parental influences on pathological symptoms of video-gaming among children and adolescents: A prospective study. Journal of Child and Family Studies, 24(5), 1429 1441. doi:10.1007/s10826-014-9949-9

Chng, G. S., Li, D., Liau, A. K., \& Khoo, A. (2015). Moderating effects of the family environment for parental mediation and pathological Internet use in youths. Cyberpsychology, Behavior, and Social Networking, 18(1), 30-36. doi:10.1089/ cyber.2014.0368

Cicchetti, D., Ackerman, B. P., \& Izard, C. E. (1995). Emotions and emotion regulation in developmental psychopathology. Development and Psychopathology, 7(1), 1-10. doi:10.1017/ S0954579400006301

Coulombe, M. (2010). Le monde sans fin des jeux vidéo [The never ending world of video game]. Paris: PUF.

Cutrona, C. E., Cole, V., Colangelo, N., Assouline, S. G., \& Russell, D. W. (1994). Perceived parental social support and academic achievement: An attachment theory perspective. Journal of Personality and Social Psychology, 66(2), 369-378. doi:10.1037/0022-3514.66.2.369

Da Charlie, C. W., HyeKyung, C., \& Khoo, A. (2011). Role of parental relationships in pathological gaming. Procedia Social and Behavioral Sciences, 30, 1230-1236. doi:10.1016/j. sbspro.2011.10.238

Davids, E. L., Roman, N. V., \& Leach, L. (2017). The link between parenting approaches and health behavior: A systematic review. Journal of Human Behavior in the Social Environment, 27(6), 589-608. doi:10.1080/10911359.2017.1311816

Denham, S. A., Blair, K. A., DeMulder, E., Levitas, J., Sawyer, K., Auerbach-Major, S., \& Queenan, P. (2003). Preschool emotional competence: Pathway to social competence. Child Development, 74(1), 238-256. doi:10.1111/1467-8624.00533

Diamond, G. M., Diamond, G. S., \& Liddle, H. A. (2000). The therapist-parent alliance in family-based therapy for adolescents. Journal of Clinical Psychology, 56(8), 1037-1050. doi:10.1002/ 1097-4679(200008)56:8<1037::AID-JCLP4>3.0.CO;2-4

Diamond, G. S., \& Liddle, H. A. (1996). Resolving a therapeutic impasse between parents and adolescents in multidimensional family therapy. Journal of Consulting and Clinical Psychology, 64(3), 481-488. doi:10.1037/0022-006X.64.3.481

Diamond, G. S., \& Liddle, H. A. (1999). Transforming negative parent-adolescent interactions: From impasse to dialogue. Family Process, 38(1), 5-26. doi:10.1111/j.1545-5300.1999.00005.x

Diamond, G. M., Liddle, H. A., Hogue, A., \& Dakof, G. A. (1999). Alliance-building interventions and adolescents in multidimensional family therapy. Journal of Consulting and Clinical Psychology, 64(3), 481-488. doi:10.1037/0022-006X.64.3.481

Dix, T. (1991). The affective organization of parenting: Adaptive and maladaptive processes. Psychological Bulletin, 110(1), 3-25. doi:10.1037/0033-2909.110.1.3 
Doane, J. A., Hill, W. L., \& Diamond, D. (1991). A developmental view of therapeutic bonding in the family: Treatment of the disconnected family. Family Process, 30, 155-176.

Donovan, J. E. (2004). Adolescent alcohol initiation: A review of psychosocial risk factors. Journal of Adolescent Health, 35(6), 529.e7-529.e18. doi:10.1016/j.jadohealth.2004.02.003

Dubois-Comtois, K., Cyr, C., Pascuzzo, K., Lessard, M., \& Poulin, C. (2013). Attachment theory in clinical work with adolescents. Journal of Child and Adolescent Behavior, 1(3), 1-8. doi: $10.4172 /$ jcalb. 1000111

Eisenberg, N., Spinrad, T. L.Losoya, S. H., \& Morris, A. S. (2002). Regulation, resiliency, and quality of social functioning. Self \& Identity, 1(2), 121-128. doi:10.1080/152988602317319294

Estévez, A., Jàuregui, P., Sànchez-Marcos, I., Lopez-Gonzàlez, H., \& Griffiths, M. (2017). Attachment and emotion regulation in substance addictions and behavioral addictions. Journal of Behavioral Addictions, 6(4), 534-544. doi:10.1556/2006.6. 2017.086

Federman, E. J., Drebing, C. E., \& Krebs, C. (2000). Don't leave it to chance. Oakland, CA: New Harbinger Publications, Inc.

Floros, G., \& Siomos, K. (2013). The relationship between optimal parenting, Internet addiction and motives for social networking in adolescence. Psychiatry Research, 209(3), 529-534. doi:10.1016/j.psychres.2013.01.010

Fonagy, P., \& Bateman, A. W. (2005). Attachment theory and mentalization-oriented model of borderline personality disorder. In J. M. Oldham, A. E. Skodol, \& D. S. Bender (Eds.), Textbook of personality disorders (pp. 187-207). Washington, DC: American Psychiatric Publishing.

Franklin, J. C., Jamieson, J. P., Glenn, C. R., \& Nock, M. K. (2015). How developmental psychopathology theory and research can inform the research domain criteria (RDoC) project. Journal of Clinical Child and Adolescent Psychology, 44(2), 280-290. doi:10.1080/15374416.2013.873981

Frick, P., \& Morris, A. S. (2004). Temperament and developmental pathways to severe conduct problems. Journal of Clinical Child and Adolescent Psychology, 33(1), 54-68. doi:10.1207/ S15374424JCCP3301_6

Friedlander, M. L., Escudera, V., \& Heatherington, L. (2006). Therapeutic alliances in couple and family therapy: An empirical informed guide to practice. Washington, DC: American Psychological Association.

Friedlander, M. L., Escudera, V., Heatherington, L., \& Diamond, G. M. (2011). Alliance in couple and family therapy. In J. Norcross (Ed.), Psychotherapy relationships that work (2nd ed., pp. 92-109). Washington, DC: American Psychological Association.

Garnefski, N. (2000). Age differences in depressive symptoms, antisocial behavior, and negative perceptions of family, school, and peers among adolescents. Journal of the American Academy of Child and Adolescent Psychiatry, 39, 1175-1181. doi:10.1097/00004583-200009000-00018

Gentile, D. A. (2009). Pathological video-game use among youth ages 8-18. Psychological Science, 20(5), 594-602. doi:10.1111/j.1467-9280.2009.02340.x

Granic, I., Lobel, A., \& Engels, R. (2014). The benefits of playing video games. American Psychologist, 69(1), 66-78. doi:10. 1037/a0034857

Griffiths, M. D., Van Rooij, A. J., Kardefelt-Winther, D., Starcevic, V., Király, O., Pallesen, S., Müller, K., Dreier, M., Carras, M.,
Prause, N., King, D. L., Aboujaoude, E., Kuss, D. J., Pontes, H. M., Lopez Fernandez, O., Nagygyorgy, K., Achab, S., Billieux, J., Quandt, T., Carbonell, X., Ferguson, C. J., Hoff, R. A., Derevensky, J., Haagsma, M. C., Delfabbro, P., Coulson, M., Hussain, Z., \& Demetrovics, Z. (2016). Working towards an international consensus on criteria for assessing Internet gaming disorder: A critical commentary on Petry et al. (2014). Addiction, 111(1), 167-175. doi:10.1111/add.13057

Halberstadt, A. G., Denham, S. A., \& Dunsmore, J. C. (2001). Affective social competence. Social Development, 10, 79-119. doi:10.1111/1467-9507.00150

Hayes, S. C., Wilson, K. G., Gifford, E. V., \& Follette, V. M. (1996). Experiential avoidance and behavioral disorders: A functional dimensional approach to diagnosis and treatment. Journal of Consulting and Clinical Psychology, 64(6), 1152-1168. doi:10.1037/0022-006X.64.6.1152

Henderson, C. E., Dakof, G. A., Greenbaum, P. E., \& Liddle, H. A. (2010). Effectiveness of multidimensional family therapy with higher severity substance-abusing adolescents: Report from two randomized controlled trials. Journal of Consulting and Clinical Psychology, 78(6), 885-897. doi:10. 1037/a0020620

Henderson, C. E., Rowe, C. L., Dakof, G. A., Hawcs, S. W., \& Liddle, H. A. (2009). Parenting practices as mediators ot treatment effects in an early-intervention trial of multidimensional family therapy. American Journal of Drug and Alcohol Abuse, 35(4), 220-226. doi:10.1080/00952990903005890

Hershenberg, R., \& Goldfried, M. R. (2015). Implications of RDoC for the research and practice of psychotherapy. Behavior Therapy, 46(2), 156-165. doi:10.1016/j.beth.2014.09.014

Higham, J. E., Friedlander, M. L., Escudero, V., \& Diamond, G. (2012). Engaging reluctant adolescents in family therapy: An exploratory study of in-session processes of change. Journal of Family Therapy, 34(1), 24-52. doi:10.1111/j.1467-6427.2011. 00571.x

Hill, J. P., \& Holmbeck, G. N. (1986). Attachment and autonomy during adolescence. Annals of Child Development, 3, 145-189. doi:10.1037//0022-006X.70.1.56

Huey, S. J., Henggeler, S. W., Brondino, M. J., \& Pickrel, S. G. (2000). Mechanisms of change in multisystemic therapy: Reducing delinquent behavior through therapist adherence and improved family and peer functioning. Journal of Consultingand Clinical Psychology, 68(3), 451-467. doi:10.1037/0022006X.68.3.451

Jeong, E. J., \& Kim, D. H. (2011). Social activities, self-efficacy, game attitudes, and game addiction. Cyberpsychology, Behavior, and Social Networking, 14(4), 213-221. doi:10.1089/ cyber.2009.0289

Kaltiala-Heino, R., Koivisto, A., Marttunen, M., \& Fröjd, S. (2011). Pubertal timing and substance use in middle adolescence: A 2-year follow-up study. Journal of Youth and Adolescence, 40(10), 1288-1301. doi:10.1007/s10964-011-9667-1

Kaminski, J. W., Puddy, R. W., Hall, D. M., Cashman, S. Y., Crosby, A. E., \& Ortega, L. A. G. (2010). The relative influence of different domains of social connectedness on self-directed violence in adolescence. Journal of Youth and Adolescence, 39(5), 460-473. doi:10.1007/s10964-009-9472-2

Kardefelt-Winther, D., Heeren, A., Schimmenti, A., Rooij, A., Maurage, P., Carras, M., Edman, J., Blaszczynski, A., Khazaal, Y., \& Billieux, J. (2017). How can we conceptualize 
behavioural addiction without pathologizing common behaviours? Addiction, 112(10), 1709-1715. doi:10.1111/ add. 13763

Keijsers, L. (2016). Parental monitoring and adolescent problem behaviors: How much do we really know? International Journal of Behavioral Development, 40(3), 271-281. doi:10.1177/0165025415592515

King, D. L., \& Delfabbro, P. H. (2016). The cognitive psychopathology of Internet gaming disorder in adolescence. Journal of Abnormal Child Psychology, 44(8), 1635-1645. doi:10.1007/ s10802-016-0135-y

King, D. L., Delfabbro1, P. H., Doh, Y. Y., Wu, A. M. S., Kuss, D. J., Pallesen, S., Mentzoni, R., Carragher, N., \& Sakuma, H. (2018). Policy and prevention approaches for disordered and hazardous gaming and Internet use: An international perspective. Prevention Science, 19(2), 233-249. doi:10.1007/s11121-0170813-1

King, D. L., Delfabbro, P. H., Potenza, M. N., Demetrovics, Z., Billieux, J., \& Brand, M. (2018). Internet gaming disorder should qualify as a mental disorder. Australian and New Zealand Journal of Psychiatry, 52(7), 615-617. doi:10.1177/ 0004867418771189

King, D. L., Delfabbro, P. H., Wu, A. M. S., Doh, Y. Y., Kuss, D. J., Pallesen, S., Mentzonie, R., Carragherf, N., \& Sakuma, H. (2017). Treatment of Internet gaming disorder: An international systematic review and CONSORT evaluation. Clinical Psychology Review, 54, 123-133. doi:10.1016/j.cpr.2017.04.002

King, K. M., Molina, B. S. G., \& Chassin, L. (2009). Prospective relations between growth in drinking and familial stressors across adolescence. Journal of Abnormal Psychology, 118(3), 610-622. doi:10.1037/a0016315

Ko, C., Yen, J., Chen, S., Wang, P., Chen, C., \& Yen, C. (2014). Evaluation of the diagnostic criteria of Internet gaming disorder in the DSM-5 among young adults in Taiwan. Journal of Psychiatric Research, 53, 103-110. doi:10.1016/j.jpsychires. 2014.02.008

Kourgiantakis, T., Saint-Jacques, M. C., \& Tremblay, J. (2013). Problem gambling and families: A systematic review. Journal of Social Work Practice in the Addictions, 13(4), 353-372. doi:10.1080/1533256X.2013.838130

Kuss, D. J., \& Griffiths, M. D. (2012). Online gaming addiction in adolescence: A literature review of empirical research. Journal of Behavioral Addictions, 1(1), 3-22. doi:10.1556/JBA.1. 2012.1.1

Kwon, J. H., Chung, C. S., \& Lee, J. (2011). The effects of escape from self and interpersonal relationship on the pathological use of Internet games. Community Mental Health Journal, 47(1), 113-121. doi:10.1007/s10597-009-9236-1

Liau, A. K., Choo, H., Li, D. D., Gentile, D. A., Sim, T., \& Khoo, A. (2015). Pathological video-gaming among youth: A prospective study examining dynamic protective factors. Addiction Research \& Theory, 23(4), 301-308. doi:10.3109/16066359.2014.987759

Liddle, H. A. (1995). Conceptual and clinical dimensions of a multidimensional, multisystems engagement strategy in family based adolescent treatment. Psychotherapy, 32(1), 39-58. doi:10.1037/0033-3204.32.1.39

Liddle, H. A. (2000). Multidimensional family therapy for adolescent cannabis users. Cannabis youth treatment series, Vol. 5. Substance abuse and mental health services administration (DHHS/PHS). Rockville, MD: Center for Substance Abuse Treatment.
Liddle, H. A. (2010). Multidimensional family therapy: A sciencebased treatment system. The Australian and New Zealand Journal of Family Therapy, 31(2), 133-148. doi:10.1375/anft. 31.2.133

Liddle, H. A. (2016a). Multidimensional family therapy: Evidence base for transdiagnostic treatment outcomes, change mechanism, and implementation in community settings. Family Process, 55(3), 558-576. doi:10.1111/famp.12243

Liddle, H. A. (2016b). Multidimensional family therapy. In T.L. Sexton \& J. Lebow (Eds.), Handbook of family therapy (pp. 231-249). New York, NY: Routledge/Taylor \& Francis Group.

Liddle, H. A., Dakof, G. A., \& Diamond, G. S. (1991). Multidimensional family therapy with adolescent substance abuse. In E. Kaufman \& P. Kaufman (Eds.), Family therapy approaches with drug and alcohol problems (pp. 120-178). Boston, MA: Allyn and Bacon.

Liddle, H. A., Dakof, G. A., Henderson, C. E., \& Rowe, C. L. (2011). Implementation outcomes of multidimensional family therapy-detention to community: A reintegration program for drug-using juvenile detainees. International Journal of Offender Therapy and Comparative Criminology, 55(4), 587-604. doi:10.1177/0306624X10366960

Liddle, H. A., Dakof, G. A., Parker, K., Diamond, G. S., Barrett, K., \& Tejada, M. (2001). Multidimensional family therapy for adolescent substance abuse: Results of a randomized clinical trial. American Journal of Drug and Alcohol Abuse, 27(4), 651-688. doi:10.1081/ADA-100107661

Liddle, H. A., \& Rigter, H. (2013). How developmental research and contextual theory drive clinical work with adolescents with addiction. Substance Abuse, 21(4), 200-204. doi:10.1097/ HRP.0b013e31829aaa6b

Liddle, H. A., Rowe, C. L., Dakof, G. A., Henderson, C. E., \& Greenbaum, P. E. (2009). Multidimensional family therapy for young adolescent substance abuse: Twelve-month outcomes of a randomized controlled trial. Journal of Consulting and Clinical Psychology, 77(1), 12-25. doi:10.1037/a0014160

Liddle, H. A., Rowe, C. L., Dakof, G., \& Lyke, J. (1998). Translating parenting research into clinical interventions for families of adolescents. Clinical Child Psychology and Psychiatry, 3(3), 419-443. doi:10.1177/1359104598033007

Livingstone, S. (2007). Strategies of parental regulation in the media-rich home. Computers in Human Behavior, 23(2), 920-941. doi:10.1016/j.chb.2005.08.002

Lupton, D. (1998). The emotional self. A sociocultural exploration. London, UK: Sage Publications.

Lyon, M., \& Bardalet, J. (1994). Society's body: Emotion and the "somatization" of social theory. In T. Csordas (Ed.), Emodiment and experience: The existential ground of culture and self (pp. 48-66). Cambridge, UK: Cambridge University Press.

Maccoby, E. E., \& Martin, J. A. (1983). Socialization in the context of the family: Parent-child interaction. In P. H. Mussen \& E. M. Hetherington (Eds.), Handbook of child psychology: Vol. 4. Socialization, personality, and social development (4th ed.). New York, NY: Wiley.

Mann, B. J., Borduin, C. M., Henggeler, S. W., \& Blaske, D. M. (1990). An investigation of systematic conceptualizations of parent-child coalitions and symptom change. Journal of Consulting and Clinical Psychology, 58(3), 336-344. doi:10.1037/ 0022-006X.58.3.336 
Martin, D. J., Garske, J. P., \& Davis, M. K. (2000). Relation of the therapeutic alliance with outcome and other variables: A metaanalytic review. Journal of Consulting and Clinical Psychology, 68(3), 438-450. doi:10.1037/0022-006X.68.3.438

McMahon, R. J., Forehand, R., Griest, D. L., \& Wells, K. C. (1981). Who drops out of treatment during parent behavior training? Behavioral Counseling Quarterly, 1, 79-85.

Morris, A. S., Silk, J. S., Steinberg, L., Myers, S. S., \& Robinson, L. R. (2007). The role of the family context in the development of emotion regulation. Social Development, 16(2), 361-388. doi:10.1111/j.1467-9507.2007.00389.x

Muck, R., Zempolich, K. A., Titus, J. C., Fishman, M., Godley, M. D., \& Schwebel, R. (2001). An overview of the effectiveness of adolescent substance abuse treatment models. Youth and Society, 33(2), 143-168. doi:10.1177/0044118X0 1033002002

Mesch, G. S. (2009). Parental mediation, online activities, and cyberbullying. CyberPsychology \& Behavior, 12(4), 387-393. doi:10.1089/cpb.2009.0068.

Newman, K., Harrison, L., Dashiff, C., \& Davies, S. (2008). Relationships between parenting styles and risk behaviors in adolescent health: An integrative literature review. Revista Latino-Americana de Enfermagem, 16(1), 142-150. doi:10. 1590/S0104-11692008000100022

Patterson, G. R., \& Chamberlain, P. (1994). A functional analysis of resistance during parent training therapy. Clinical Psychology: Science and Practice, 1, 53-70. doi:10.1111/j.14682850.1994.tb00006.x

Ramirez, E. R., Norman, G. J., Rosenberg, D. E., Kerr, J., Saelens, B. E., Durant, N., \& Sallis, J. F. (2011). Adolescent screen time and rules to limit screen time in the home. Journal of Adolescent Health, 48(4), 379-385. doi:10.1016/j.jadohealth. 2010.07.013

Rehbein, F., \& Baier, D. (2013). Family-, media-, and schoolrelated risk factors of video game addiction: A 5-year longitudinal study. Journal of Media Psychology: Theories Methods and Applications, 25(3), 118-128. doi:10.1027/1864-1105/ a000093

Repetti, R. L., Taylor, S. E., \& Seeman, T. E. (2012). Risky families: Family social environments and the mentaland physical health of offspring. Psychological Bulletin, 128(2), 330-366. doi:10.1037/0033-2909.128.2.330

Resnick, M., Bearman, P. S., Blum, R. W., Bauman, K. E., Harris, K. M., Jones, J., Tabor, J., Beuhring, T., Sieving, R. E., Shew, M., Ireland, M., Bearinger, L. H., \& Udry, J. R. (1997). Protecting adolescents from harm. JAMA, 278(10), 823-832. doi:10.1001/jama.1997.03550100049038

Riesch, S. K., Anderson, L. S., Pridham, K. A., Lutz, K. F., \& Becker, P. T. (2010). Furthering the understanding of parentchild relationships: A nursing scholarship review series. Part 5: Parent-adolescent and teen parent-child relationships. Journal for Specialists in Pediatric Nursing, 15(3), 182-201. doi:10.1111/j.1744-6155.2009.00228.x

Rikkers, W., Lawrence, D., Hafekost, J., \& Zubrick, S. R. (2016). Internet use and electronic gaming by children and adolescents with emotional and behavioural problems in Australia Results from the second Child and Adolescent Survey of Mental Health and Wellbeing. BMC Public Health, 16, 399. doi:10.1186/s12889-016-3058-1.

Robbins, M. S., Alexander, J. F., Newell, R. M., \& Turner, C. W. (1996). The immediate effect of reframing on client attitude in family therapy. Journal of Family Psychology, 10(1), 28-34. doi:10.1037/0893-3200.10.1.28

Robbins, M. S., Liddle, H. A., Turner, C. W., Dakof, G. A., \& ALexander, J. F. (2006). Adolescent and parent therapeutic alliances as predictors of dropout in multidimensional family therapy. Journal of Family Psychology, 20(1), 108-116. doi:10.1037/0893-3200.20.1.108

Rosen, L. D., Cheever, N. A., \& Carrier, M. L. (2008). The association of parenting style and child age with parental limit setting and adolescent MySpace behavior. Journal of Applied Developmental Psychology, 29(6), 459-471. doi:10.1016/ j.appdev.2008.07.005

Rubenstein, A. K. (2005). Methods to engage the reluctant adolescent. In G. P. Koocher, J. C. Norcross, \& S. S. Hill (Eds.), Psychologists' desk reference (2nd ed., pp. 1169-1175). New York, NY: Oxford University Press.

Rumpf, H. J., Achab, S., Billieux, J., Bowden-Jones, H., Carragher, N., Demetrovics, Z., Higuchi, S., King, D. L., Mann, K., Potenza, M., Saunders, J. B., Abbott, M., Ambekar, A., Aricak, O. T., Assanangkornchai, S., Bahar, N., Borges, G., Brand, M., Chan, E. M., Chung, T., Derevensky, J., Kashef, A. E., Farrell, M., Fineberg, N. A., Gandin, C., Gentile, D. A., Griffiths, M. D., Goudriaan, A. E., Grall-Bronnec, M., Hao, W., Hodgins, D. C., Ip, P., Király, O., Lee, H. K., Kuss, D., Lemmens, J. S., Long, J., Lopez-Fernandez, O., Mihara, S., Petry, N. M., Pontes, H. M., Rahimi-Movaghar, A., Rehbein, F., Rehm, J., Scafato, E., Sharma, M., Spritzer, D., Stein, D. J., Tam, P., Weinstein, A., Wittchen, H. U., Wölfling, K., Zullino, D., \& Poznyak, V. (2018). Including gaming disorder in the ICD-11: The need to do so from a clinical and public health perspective. Journal of Behavioral Addictions, 7(3), 556-561. doi:10.1556/2006.7.2018.59

Runkel, A. L., Christenson, J. D., Glunz, A. P., \& Cobb, K. F. (2017). Readiness for change within the family and the identified patient. In J. D. Christenson \& A. N. Merritts (Eds.), Family therapy with adolescents in residential treatment. Focused issues in family therapy. (pp. 245-262). Cham, Switzerland: Springer.

Schmidt, S. E., Liddle, H. A., \& Dakof, G. A. (1996). Changes in parental practices and adolescent drug abuse during multidimensional family therapy. Journal of Family Psychology, 10(1), 12-27. doi:10.1037/0893-3200.10.1.12

Schneider, L. A., King, D. L., \& Delfabbro, P. H. (2017). Family factors in adolescent problematic Internet gaming: A systematic review. Journal of Behavioral Addictions, 6(3), 321-333. doi:10.1556/2006.6.2017.035

Shek, D. T. L., Tang, V. M. Y., \& Lo, C. Y. (2009). Evaluation of an Internet addiction treatment program for Chinese adolescents in Hong Kong. Adolescence, 44, 359-373.

Shelef, K., Diamond, G. M., Diamond, G. S., \& Liddle, H. A. (2005). Adolescent and parent alliance and treatment outcome in multidimensional family therapy. Journal of Consulting and Clinical Psychology, 73(4), 689-698. doi:10.1037/0022006X.73.4.689

Shin, W., \& Huh, J. (2011). Parental mediation of teenagers' videogame playing: Antecedents and consequences. New Media and Society, 13(6), 945-962. doi:10.1177/1461444 810388025

Sloan, E., Hall, K., Moulding, R., Bryce, S., Mildred, H., \& Staiger, P. K. (2017). Emotion regulation as a transdiagnostic treatment construct across anxiety, depression, substance, eating and 
borderline personality disorders: A systematic review. Clinical Psychology Review, 57, 141-163. doi:10.1016/j.cpr.2017. 09.002

Sorensen, P. B. (2005). Changing positions: Helping parents look through the child's eyes. Journal of Child Psychotherapy, 31(2), 153-168. doi:10.1080/00754170500221204

Stark, M. J. (1992). Dropping out of substance abuse treatment: A clinically oriented review. Clinical Psychology Review, 12(1), 93-116. doi:10.1016/0272-7358(92)90092-M

Steinberg, L. (2001). We know some things: Adolescent-parent relationships in retrospect and prospect. Journal of Research on Adolescence, 11(1), 1-19. doi:10.1111/1532-7795.00001

Steinberg, L. (2004). The ten basic principles of good parenting. New York, NY: Simon \& Schuster.

Steinberg, L. (2008). A social neuroscience perspective on adolescent risk taking. Developmental Review, 28(1), 78-106. doi:10.1016/j.dr.2007.08.002

Steinberg, L. (2014). Adolescence. New York, NY: McGraw-Hill Education.

Steinberg, L., \& Levine, A. (1997). You and your adolescent. A parent's guide for ages 10-20. New York, NY: Harper Perennial.

Stevens, S. J., \& Morral, A. R. (2003). Adolescent substance abuse treatment in the United States: Exemplary models from a national evaluation study. Binghampton, NY: Haworth Press.

Tafa, M., \& Baiocco, R. (2009). Addictive behavior and family functioning during adolescence. American Journal of Family Therapy, 37, 388-395. doi:10.1080/01926180902754745

Tanner-Smith, E. E., Jo Wilson, S., \& Lipsey, M. W. (2013). The comparative effectiveness of outpatient treatment for adolescent substance abuse: A meta-analysis. Journal of Substance Abuse Treatment, 44(2), 145-158. doi:10.1016/j.jsat.2012.05.006

Teasdale, J. D., \& Fogarty, S. J. (1979). Differential effects of induced mood on retrieval of pleasant and unpleasant events from episodic memory. Journal of Abnormal Psychology, 88(3), 248-257. doi:10.1037/0021-843X.88.3.248

Tunney, R. J., \& James, R. J. E. (2017). Criteria for conceptualizing behavioural addiction should be informed by the underlying behavioural mechanism. Addiction, 112(10), 1720-1721. doi:10.1111/add.13831

Vollmer, C., Randler, C., Horzum, M. B., \& Ayas, T. (2014). Computer game addiction in adolescents and its relationship to chronotype and personality. Sage Open, 4(1), 2158244 01351805-9. doi:10.1177/2158244013518054

Waldron, H. B., Brody, J. L., Robbins, M. S., \& Alexander, J. F. (2013). Functional family therapy for adolescent substance use disorders. In P. M. Miller, S. A. Ball, M. E. Bates, A. W. Blume, K. M. Kampman, D. J. Kavanagh, M. E. Larimer, P. M. Nancy, \& P. De Witte (Eds.), Comprehensive addictive behaviors and disorders (Vol.3): Interventions for addiction (pp. 109-116). San Diego, CA: Elsevier Academic Press.
Wallenius, M., \& Punamäki, R. L. (2008). Digital game violence and direct aggression in adolescence: A longitudinal study of the roles of sex, age, and parent-child communication. Journal of Applied Developmental Psychology, 29(4), 286-294. doi:10.1016/j.appdev.2008.04.010

Wallenius, M., Rimpelä, A., Punamäki, R.-L., \& Lintonen, T. (2009). Digital game playing motives among adolescents: Relations to parent-child communication, school performance, sleeping habits, and perceived health. Journal of Applied Developmental Psychology, 30(4), 463-474. doi:10.1016/ j.appdev.2008.12.021

Wang, C. W., Chan, C. L. W., Mak, K K., Ho, S. Y., Wong, P. W. C., \& Ho, R. T. H. (2014). Prevalence and correlates of video and Internet gaming addiction among Hong Kong adolescents: A pilot study. The Scientific World Journal, 2014, 874648. doi:10.1155/2014/874648

Wang, M., Dishion, T., Stormshak, E., \& Willett, J. (2011). Trajectories of family management practices and early adolescent behavioral outcomes. Developmental Psychology, 47(5), 1324-1341. doi:10.1037/a0024026

Weinberg, N. Z., Rahdert, E., Colliver, J. D., \& Glantz, M. D. (1998). Adolescent substance abuse: A review of the past 10 years. Journal of the American Academy of Child \& Adolescent Psychiatry, 37(3), 252-261. doi:10.1097/ 00004583-199803000-00009

Wichstrøm, L., Frode Stenseng, F., Belsky, J., von Soest, T., \& Hygen, B. W. (2018). Symptoms of Internet gaming disorder in youth: Predictors and comorbidity. Journal of Abnormal Child Psychology, 47(1), 71-83. doi:10.1007/s10802-018-0422-x

World Health Organization (WHO). 2018. The ICD-11 classification of mental and behavioral disorders: Diagnostic criteria for research. Geneva, Switzerland: World Health Organization.

Yang, S. C., \& Tung, C. J. (2007). Comparison of Internet addicts and non-addicts in Taiwanese high school. Computers in Human Behavior, 23(1), 79-96. doi:10.1016/j.chb. 2004.03.037

Youniss, J., \& Smollar, J. (1985). Adolescent relations with mothers, fathers and friends. Chicago, IL: University of Chicago Press.

Zajac, K., Ginley, M. K., Chang, R., \& Petry, N. M. (2017). Treatments for Internet gaming disorder and Internet addiction: A systematic review. Psychology of Addictive Behaviors, 31(8), 979-994. doi:10.1037/adb0000315

Zhu, J. J., Zhang, W., Yu, C. F., \& Bao, Z. Z. (2015). Early adolescent Internet game addiction in context: How parents, school, and peers impact youth. Computers in Human Behavior, 50, 159-168. doi:10.1016/j.chb.2015.03.079

Zorbaz, S. D., Ulas, O., \& Kizildag, S. (2015). Relation between video game addiction and interfamily relationships on primary school students. Educational Sciences: Theory \& Practice, 15, 489-497. doi:10.12738/estp.2015.2.2601 